\title{
Spreading the News within the Clerical Profession: Newspapers and the Church in the North of England, $1660-1760$
}

\author{
Daniel Reed
}

In 1748, Montesquieu observed that the British knew better "than any other people upon earth how to value [the] three great advantages, religion, commerce, and liberty". ${ }^{1}$ The provincial newspapers that appeared in Britain from the first decade of the eighteenth century strongly reflected a society in which these strands of life were tightly intertwined. As Jonathan Clark describes, in this period the Church often acted as the ubiquitous agent of the State, "quartering the land not into a few hundred constituencies but into ten thousand parishes". ${ }^{2}$ In many respects, the early provincial newspapers that served this national mosaic of parochial communities reveal the centrality of religion to everyday life in eighteenth-century Britain. The affairs of the Church featured prominently alongside diplomatic and mercantile intelligence as the content of news reports, and the clergy acted as key consumers of newspapers, and agents in spreading the news. Despite this, religion has often been allotted a minor role in the discussion of newspaper development, in which the commercial aspects of the printing trade have been emphasised to serve a narrative of Enlightenment discourse founded on theories of secularisation. ${ }^{3}$ This essay argues that the emergence of newspapers to serve provincial markets represented a new transformation in the long-standing relationship between the established Church and print which began with the introduction of the press to England in the fifteenth century.

1 Baron de Montesquieu, The Spirit of the Laws, trans. Thomas Nugent (New York: Hafner, 1949), p. 321, quoted in Gertrude Himmelfarb, The Roads to Modernity: The British, French, and American Enlightenments (New York: Vintage, 2004), p. $5^{2 .}$

2 J.C.D. Clark, English Society 166o-1832 (Cambridge: Cambridge University Press, 200o), p. 320.

3 William Gibson, 'Introduction: New Perspectives on Secularisation in Britain (and Beyond)' Journal of Religious History, 41:4 (2017), pp. 431-438. 
Historians such as Andrew Pettegree and Jeremy Black have outlined the centrality of religion to the rise of print culture in the early modern period. ${ }^{4}$ The appearance in 1620 of the first newspapers in English was an innovation to supply a nation eager for news, but it is clear that this form of report, including ecclesiastical intelligence, was modelled on other long-standing traditions of manuscript and oral news transmission. ${ }^{5}$ A report in Nathaniel Butter's newsbook of 18 September 1622, that the Dean of Paris had received the consent of the French king to succeed his brother as bishop of the city, but had fallen sick and died on his journey to Rome, would have been instantly recognisable to eighteenth-century readers of the first English provincial newspapers. ${ }^{6}$ This can be attributed in some measure to the influence of manuscript news, which continued to play an important role in news transmission in eighteenthcentury Britain. Surviving manuscript newsletters issued during the reigns of William III and Anne demonstrate that Church affairs were reported alongside other regular dispatches, and closely followed the development of religious controversies, such as the trial of the High Churchman, Henry Sacheverell, in $1710 .{ }^{7}$ The form of news was also influenced by the print culture of continental Europe, where there were more open markets for the printing and sale of newspapers. In the seventeenth century, Dutch newspapers reported the affairs of the Church of England as international intelligence at a time when manuscript newsletters were still the predominant source of news outside of London. ${ }^{8}$

Taking examples from the North of England, a region with its own distinct history of printing, this essay investigates ways in which religion, primarily in the Church of England and espoused by members of the clerical profession, was a pervasive presence in early provincial newspapers. This is achieved by first considering the state of the archival record relating to early provincial

4 Andrew Pettegree, The Invention of News: How the World Came to Know About Itself (New Haven: Yale University Press, 2014); Jeremy Black, The English Press, 1621-1861 (Stroud: Sutton Publishing Group, 2001), pp. 2-3.

5 Ian Atherton, 'The Itch Grown a Disease: Manuscript Transmission of News in the Seventeenth Century', in Joad Raymond (ed.), News, Newspapers and Society in Early Modern Britain (Portland: Frank Cass \& Co., 1999), p. 39.

6 The 25. of September. Newes from most parts of christendome. Especially from Rome, Italy, Spaine, France, the Palatinate, the Low Countries, and divers other places (London: printed for Nathaniel Butter and William Sheffard, 1622), p. 3.

7 Huntington Library, HM 30659, manuscript newsletters from London, 1689-1710.

8 Arthur Der Weduwen, 'Towards a Complete Bibliography of Seventeenth-Century Dutch Newspapers: Delpher and its Applications', Tijdschrift voor tijdschriftstudies, 38 (2015), p. 21. 
newspaper titles, and secondly outlining the particular relationship between the Church and the press in the North of England from 166o. This provides a foundation for three key points of investigation: the manner in which clergymen of the Church of England were commonly represented in news reports of the period; the roles that the clergy played in the consumption and dispersal of news; and the techniques used by newspaper printers to harness the popularity of religion for commercial purposes. Furthermore, this essay engages with ongoing discussions about the usability and utility of digital newspapers in relation to other archival source material, and draws attention to evidence drawn from physical newspapers, and secondary references in account books, diaries and letters, to examine the place of the clergy (and religion more broadly) within the transforming newsprint culture of the eighteenth century.

\section{Early Provincial Newspapers: Gaps in the Digital Record}

When undertaking an investigation based on early provincial newspaper titles, it is necessary to first consider the relative value of the major newspaper databases for supporting such a study. The contents of these resources are governed by factors such as the scope of the particular digitisation project, and the limitations of the physical collection (or collections) from which the databases are derived. To take the example of the British Newspaper Archive, which is drawn from the collections of the British Library, this database currently features 762 issues of the Newcastle Courant for 1710 to 1729, but no York titles for the same period. ${ }^{9}$ And whilst this project is still underway in 2016, and it is possible that further issues will be added in the future, there are many provincial titles that the British Library does not hold, and consequently, will never appear in the database within the current compass of the project. Furthermore, archival search platforms that incorporate multiple repositories, such as Copac and the National Archives's Discovery catalogue, are currently poor for accurately locating issues of eighteenth-century newspapers. ${ }^{10}$ So, to find

9 Cataloguing conventions in major digital databases can also lack nuance. The British Newspaper Archive hosts a single copy of the Newcastle Gazette: Or Northern Courant for 23 December 1710, which is catalogued together with the Newcastle Courant, despite being identified by R.M. Wiles as a distinct and separate title. See R.M. Wiles, Freshest Advices: Early Provincial Newspapers in England (Columbus: Ohio State University Press, 1965), pp. $45^{1-452 .}$

10 Copac lists a single copy of the York Gazetteer, whereas Discovery retrieves only microfilm copies of the newspaper held at North Yorkshire County Record Office. See http://copac .jisc.ac.uk/about/ (accessed 13 June 2016). 
many early newspaper titles it is necessary to turn to other institutions, such as regional libraries and archives services.

One title that is not currently available in digital form is the short-lived York Gazetteer, notable as a reflection of the political influence wielded by the eighteenth-century Church through the newspaper's association with the clergymen Jaques and Laurence Sterne. ${ }^{11}$ Whilst the exact nature of their involvement is still under discussion, it is clear that both men were contributors to the newspaper, and had wider roles in its financing, and promotion. ${ }^{12}$ The York Gazetteer was printed by John Jackson as a mouthpiece for supporters of the Whig ministry ahead of the general election of 1741 , and a subsequent by-election for the county in January $1742 .{ }^{13}$ During the first year of the newspaper's existence, the York Gazetteer was explicit about its intended audience and political stance, stating in its colophon that it was published "to correct the Weekly Poison" of the Tory York Courant. ${ }^{14}$ Once the elections were over, however, this attack was replaced with the more commercial proposition of offering the "the fullest and most disinterested Accounts of Foreign and Domestick Affairs". 15 The latest known, extant copy of the York Gazetteer is issue 222 for 14 May 1745, although out-payments for advertising by local organisations, and notices in other newspapers, strongly suggest that the York Gazetteer was in existence until the summer of $175^{2 .}{ }^{16}$

11 Richard Hall and Sarah Richardson, The Anglican Clergy and Yorkshire Politics in the Eighteenth Century (York: University of York, 1998).

12 The York Gazetteer is important to scholars of the life and work of Laurence Sterne, as it is considered to have been the first publication to host work by the writer. Reference to Sterne's political writings for The York Gazetteer first appeared in his Memoirs, published in 1775, and the subject has been considered at length in the final instalment of the Florida editions of Sterne's works. Laurence Sterne, Letters Of The Late Rev. Mr. Laurence Sterne, To His Most Intimate Friends (London: T. Beckett, 1775); Melvyn New and W.B. Gerard (eds.), The Miscellaneous Writings and Sterne's Subscribers, an Identification List. The Florida Edition of the Works of Laurence Sterne, Volume IX (Gainesville: University Press of Florida, 2014).

13 Wiles, Freshest Advices, pp. 517-518. A single issue of the York Gazetteer survives for 1741, although its start date can be extrapolated from the numbering of later issues.

14 For the York Gazetteer and provincial newspapers in the context of partisan politics of the mid-eighteenth century, see Black, The English Press; Hannah Barker, Newspapers, Politics and English Society 1695-1855 (Harlow: Pearson Educational, 2000).

15 York Gazetteer, no. 54 (16 March 1742).

16 The terminal date of the York Gazetteer has been inferred from a notice in the York Courant for 4 August 1752, advising readers that the newspaper had ceased publication. See Wiles, Freshest Advices, p. 518. The accounts of the Assembly Rooms in York suggest, however, that the York Gazetteer was in decline some months earlier, as having formerly made 
Despite the half-century that has passed since its publication, R.M. Wiles's 'Register of English Provincial Newspapers, 1701-1760' remains the most accurate guide to locating surviving issues of the York Gazetteer, and has not been surpassed by British Library initiatives such as Newsplan, or the English Short Title Catalogue. ${ }^{17}$ In 1965 , Wiles recorded that all but one of the forty-two extant issues of the York Gazetteer were located across five highly fragmentary collections in the North of England, proximate to where the newspaper was originally published. ${ }^{18}$ This relationship between the original place of publication and present institutional holdings is even more acute in the cases of other Yorkshire newspapers of this period. All sixteen known copies of Hull's first newspaper, the Hull Courant, are held by archives services and museums in that city. ${ }^{19}$ Investigation into the current whereabouts of issues of the York Gazetteer reinforces Wiles's findings as to the geographical distribution of surviving issues, but several amendments can be made through newly identified holdings and institutional changes to previously acknowledged collections. The most significant additions are fifty-one issues held by East Riding of Yorkshire Archives \& Local Studies Service, which were presented to Beverley Public Library in 1964, and were not recorded by Wiles. ${ }^{20}$ It is the single largest

payments for advertising in the 'three York News Papers' in August 1749, similar payments in February and March $175^{2}$ were made only to the printers of the York Courant and York Journal. See York City Archives, M23: 4a, Assembly Rooms Ledger, 1732-47.

Wiles, Freshest Advices, pp. 517-518; The Newsplan project of the 1980 s sought to survey regional newspaper holdings in the United Kingdom, but prioritised the identification of longer runs of vulnerable newspapers in public libraries with a view towards producing microfilm copies. Whilst the project leaders were aware that single issues of early titles were located at other institutions, these were not investigated. As such, the project's report adds little to our knowledge of many early titles. The English Short Title Catalogue entry for the York Gazetteer is largely informed by Wiles, but also includes misleading entries such as an issue listed in the collections of McMaster University in Ontario, which is a microfilm copy of an original issue at New York Public Library. See Andrew Parkes, Report of the Newsplan Project in Yorkshire and Humberside, March 1988-June 1989 (London: The British Library, 1990); 'The York Gazetteer' in English Short Title Catalogue, http://estc .bl.uk/ (accessed 13 June 2016).

18 Wiles, Freshest Advices, pp. 517-518.

19 All known copies of the Hull Courant (1739-1750) are held at the Hull History Centre and Hull Museums Service. A volume of 183 issues was held by Hull Subscription Library at the turn of the twentieth century, but following the destruction of one of the library's premises in 1943, and subsequent dissolution of the collection in 1975, its present whereabouts is unknown. Hull History Centre, U DSL/69, Catalogue, volume 4 (Ms., Hull Subscription Library), 1889-1921.

20 Issues nos. 45-96 of the York Gazetteer for January - December 1742 were gifted to Beverley Public Library in 1964. In Pat Rogers, Essays on Pope (Cambridge: Cambridge University 
collection of copies of the York Gazetteer anywhere in the world, and the most complete run of consecutive issues. Despite this prominence, however, the collection is yet to be digitally catalogued and currently remains 'invisible' to the majority of researchers. Improvements to the digital catalogues of existing collections holds the potential for revealing previously unrecorded issues of provincial newspapers that are hidden in plain sight. ${ }^{21}$

\section{The Church and the Press - Foundations of the Newspaper Trade in the North of England}

The development of the provincial press in the North of England after the Restoration was largely governed by a special proviso in the Licensing of the Press Act of 1662, which sought to bring more strict regulation to the printing trade following the relative freedoms of the Interregnum. ${ }^{22}$ The Act designated York as the only place in the country other than London and the universities permitted to operate a press, which curtailed other printing enterprises in the region. ${ }^{23}$ The Act also stated that, in parallel with regulations for books produced at other designated centres, all "Bookes of Divinity" printed in the North

Press, 1993), the author notes that the file was "formerly in the possession of my father and was presented to [The Library] by my mother following his death". Soon after, the file came to the attention of Kenneth Monkman of the Laurence Sterne Trust, who had microfilm copies created in 1966, but those are now thought to be lost. The York Gazetteer, no. 46 (Tuesday 19 January) was loaned for display at the Laurence Sterne Bicentenary Conference in 1968, but the newspapers do not appear to have been consulted for some time thereafter. See Kenneth Monkman and J.C.T. Oates, 'Towards a Sterne Bibliography: Books and Other Material Displayed at the Sterne Conference', in Arthur H. Cash and John M. Stedmond (eds.), The Winged Skull. Papers from the Laurence Sterne Bicentenary Conference (London: Methuen \& Co., 1968), pp. 279-284.

21 In 2014, additions to the online catalogue of York Museums Trust revealed an unrecorded and unique copy of the York Gazetteer, no. 215, for 26 March 1745. See York Museums Trust, http://www.yorkmuseumstrust.org.uk/collections (accessed 13 June 2016).

'Charles II, 1662: An Act for preventing the frequent Abuses in printing seditious treasonable and unlicensed Bookes and Pamphlets and for regulating of Printing and Printing Presses', in John Raithby (ed.), Statutes of the Realm: Volume 5, 1628-8o (London: Great Britain Record Commission, 1819), pp. 428-435, available at British History Online, http:// www.british-history.ac.uk/statutes-realm/vol5/pp428-435 (accessed 1 May 2016).

23 'Charles II, 1662: An Act for preventing the frequent Abuses in printing'. The printer Stephen Bulkley produced works in Newcastle immediately following the Restoration, but relocated to York after the passing of the 1662 Act. See Richard Welford, Early Printing in Newcastle-upon-Tyne (Newcastle: Cail \& Sons, 1895), pp. 15-16. 
were to be "first licensed by the Archbishop of Yorke". ${ }^{24}$ This created a legal framework in which the Church was empowered to act for the State in regulating printing activity, and aligned the trade with renewed royal authority and the reinstatement of episcopal oversight of the Church of England. When the strictures of regulation were loosened temporarily during the Popish Plot of 1678 to 1681 , intelligence from the North appeared in unlicensed newspapers for the first time since 1662, but it does not appear that any such works were printed in York. $^{25}$

Between the implementation of the Licensing Act in 1662 and its subsequent lapse in 1695, printers in York maintained a consistent commercial relationship with the Church through the production of materials which directly supported ecclesiastical administration. As James Raven has identified, early provincial printers in England often adopted the role of jobbing stationers who derived much of their business from the demands of local governing structures. ${ }^{26}$

With the Glorious Revolution, ties between Church, Crown and the press were further strengthened through the appointment of John White as "their Majesties printer for the city of York and the five Northern counties" in recognition of his loyalty to William III in $1688 .{ }^{27}$ White printed material in support of various aspects of ecclesiastical administration and civic governance, and first displayed his Royal appointment in the imprint for a sermon of thanksgiving for the safe return of the king from Ireland, preached by George Tullie, Subdean of York, at Newcastle in October $1690 .{ }^{28}$ In the dynastic tradition of the

24 'Charles II, 1662: An Act for preventing the frequent Abuses in printing'. Following the Restoration, the Archbishop of Canterbury and Bishop of London held the authority to fill vacancies of master printers to the Stationers' Company, but this was delegated to Sir Roger L'Estrange in 1663. See Black, The English Press, p. 6; for the rights of the universities, see John Gutch, Collectanea Curiosa; or Miscellaneous Tracts, relating to the History and Antiquities of England and Ireland, The Universities of Oxford and Cambridge, vol. 1 (Oxford, 1781), pp. 278-283.

25 James Sutherland, The Restoration Newspaper and its Development (Cambridge: Cambridge University Press, 1986), p. 96.

26 James Raven, Publishing Business in Eighteenth-Century England (Woodbridge: Boydell Press, 2014), p. 75 .

27 Society of Antiquaries of London, SAL/MS/592, Warrant appointing John White to be King's printer at York; Hampton Court, 26 May 1689.

28 White printed materials in support of episcopal, archidiaconal and capitular administration. These included, Articles to be Inquired of Within the Several Parishes of the Diocess of Carlisle In the Primary and Metropolitical Visitation of ... John, ... Arch-Bishop of York (York: John White, 1693); Injunctions given by the Honourable Henry Finch, Dean of the Cathedral and Metropolitical Church in St. Peter in York(York:John White, 1705); Articles to be Enquired 
printing trade in the North of England, White headed a family which became highly influential in the development of the first newspapers in the region. ${ }^{29}$ With the 1695 lapse of the licensing laws, provincial printers further diversified the outputs of their presses, and between 1710 and 1720 the first newspapers were established at Leeds, Liverpool, Manchester and Nottingham. ${ }^{30}$ White's son founded the second (and first successful) newspaper in Newcastle-uponTyne, and in 1719, White's widow, Grace, founded York's first newspaper, the York Mercury. ${ }^{31}$ As such, newspapers became an additional output of Northern printers who had long-standing commercial and familial connections to the Church and civic governors.

\section{Reporting the Clerical Profession - Places and Preferment}

Turning to the content of early news titles, one of the most immediately observable ways in which newspapers reflected the status of the Church in eighteenth-century society was through the reporting of the preferments, changing health and deaths of clergymen, which appeared among the regular dispatches of newspaper titles throughout this period. Whilst these reports were often brief, they provided glimpses of the machinery of the clerical profession in action. Like other early provincial newspaper enterprises, printers of York's first newspapers mainly reprinted reports concerning the bishops and other dignitaries of the Church from London titles, as these individuals usually held State roles alongside their functions in the regions, creating greater

of in the Visitation, of the Reverend Knightley Chetwood, Dr. of Divinity, Arch-Deacon of the Arch-Deaconry of York (York: John White, 1705); see also University of Nottingham, Special Collections, Me x 4/3, 'Order of the Court of Quarter Sessions at Pontefract relating to the apprehension and punishment of beggars', 1700; A Sermon, Preached October, the 19, 1690. Before the Right Worshipful the Mayor, Aldermen, and Sheriff \&c. of the Town and County of New-Castle Upon Tyne (York: John White, 1691). See also Robert Davies, A Memoir of the York Press, with Notices of Authors, Printers, and Stationers, in the Sixteenth, Seventeenth, and Eighteenth Centuries (Westminster: Nichols and Sons, 1868), pp. 119-120.

29 William K. Sessions, Thomas \& Alice Broad(e), Parliamentary Printers of York from 1644, and their daughter Hannah (York: Ebor Press, 1998).

$30 \quad$ Wiles, Freshest Advices, p. 373.

31 Welford, Early Printing in Newcastle-upon-Tyne, p. 18. The Newcastle Courant was preceded only by the New-Castle Gazette, which had been founded the year prior and soon afterwards ceased publication. 
interest in their affairs. ${ }^{32}$ It is apparent, however, that by 1730 newspapers in York were drawing attention to the preferments of the more minor, local clergy. In June of that year, the Original Mercury, York Journal: Or, Weekly Courant carried a notice that Reginald Heber, rector of Marton-in-Craven in the West Riding, had received the relatively modest appointment of a chaplaincy to Brigadier Fielding's Regiment. ${ }^{33}$

Whilst reports concerning Church preferments were prevalent, they were a secondary channel of information to the flurry of epistolary and oral exchanges of intelligence that accompanied the vacancy of a position in the Church. The active application by individuals for places held a greater degree of moral acceptability in the eighteenth century, and it was not unusual for patrons to be inundated with letters and personal calls from clergymen hopeful of gaining a place. ${ }^{34}$ Producers of newspapers fuelled speculation by printing the latest rumours as to who might succeed to a position, and followed with details of appointments when the process was completed. It was not until the nineteenth century that excessive self-recommendation came to be more generally viewed as worldly and unspiritual, but there were recognised limitations in the eighteenth century to the level of importunity deemed appropriate. ${ }^{35}$ Those that exceeded these conventions were satirised by critics such as the clergyman Lewis Stephens, who in 1743 acknowledged the degree to which printed reports had become an adjunct to the unseemly business of gathering intelligence about the health of clergymen and expected vacancies, describing a known bishops' informant as a "sly downfaced walking News paper". ${ }^{36}$

32 For the structure of the Church of England in the eighteenth century see Norman Sykes, Church and State in England in the XVIIIth Century (Cambridge: Cambridge University Press, 1934).

33 Original Mercury, YorkJournal: Or, Weekly Courant, no. $25^{2}$ (Tuesday 9 June 1730).

34 To give an example from the Southern Province, Archbishop William Wake received several letters regarding the death of the master of the Hospital of St. Cross in Winchester in 1728. Wake granted the sinecure to his son-in-law, John Lynch. Cornwall Record Office. $\mathrm{PB} / 8 / 7$, letter book of William Wake, 1728-1729.

William Gibson, “Importunate Cries of Misery": the Correspondence of Lucius Henry Hibbins and the Duke of Newcastle, 1741-58', The British Library Journal, 17:1 (1991), pp. 87-93.

36 Lewis Stephens (1689-1747) served as domestic chaplain successively to bishops Sir Jonathan Trelawny, Charles Trimnell, and Lancelot Blackburne. In the mid-173os, Stephens broke ties with Blackburne and dedicated the rest of his life to his existing clerical engagements, and to study; 'The Ecclesiastical Climbers' can be found among manuscript letters of Lewis Stephens. See Cornwall Record Office, G/1968, letter book from Lewis Stephen to Francis Gregor, c. 1710-1747. 
Inevitably, given their age and social status, those who occupied the highest stations of the Church were most often subjected to frequent speculation concerning their clerical positions. Surviving correspondence demonstrates that within a decade of the appearance of the first daily newspaper in Britain, churchmen had grown wary of the attention paid to their affairs. In October 1712, Edmund Gibson informed the Bishop of Carlisle that persistent rumours in the press of the Archbishop of Canterbury's ill-health were unfounded:

You will hear repeated accounts of his Graces illness from the publick papers for which there has been no more ground than this. That the Town being thin and little company coming he intermitted his publick days, \& happened a little after to have something of the Gravel: but as to Health, you may depend upon it he is hearty and well. ${ }^{37}$

The very oldest members of the Church often felt the glare of newspaper writers most acutely, as acknowledged by the eighty-eight year old John Hough, Bishop of Worcester, in February 1739:

I heard indeed that the Gout had made some discovery of itself in your Lords ${ }^{p s}$ stomach; but the report gave me no such disturbance; for it came only from the common News Writers, who watch the Constitutions of those who are Eminent in Themselves, or in their Stations, as narrowly as the Physition: who make the most of every trifling indisposition, and sometimes amuse us with mere fiction. ... those Gentlemen have once or twice stooped so low as to myself; but their intimations were groundless. ${ }^{38}$

Lancelot Blackburne, Archbishop of York from 1724 to 1743, suffered from recurrent bouts of serious ill-health for the last fifteen years of his life, which interrupted his personal attendance on his diocese and determined the manner in which the archbishop organised his administration in the North. Whereas this has often been mistaken by historians for outright neglect of his diocesan duties, the ability to search across many newspaper sources using the digital databases for this period reveals the degree to which both London and provincial newspapers reported on the changing state of Blackburne's health over

\footnotetext{
37 Bodleian Library, Add. MS. A. 269, copy letter from Edmund Gibson to William Nicolson, 4 October 1712. Thomas Tenison, Archbishop of Canterbury, died in December 1715.

38 University of St. Andrews, MS. 5410, letter from John Hough to Edmund Gibson, 11 February 1739 .
} 
many years. ${ }^{39}$ These reports reached their most fevered state in the summer of 1734, when several newspapers printed an erroneous account that Blackburne had died at his palace at Bishopthorpe. This caused confusion in the press for the full week of 30 June to 6 July 1734, with various prints retracting and contradicting one another in the details of the archbishop's passing. ${ }^{40}$ When the reports were eventually revealed to be false, Blackburne's subsequent recovery provided ample ammunition for satirists. In August 1734, a Latin epigram titled, "To his Grace the [Lord Archbishop] of York on his Recovery after being mention'd as dead in the News-papers", appeared in The Gentleman's Magazine, and was soon followed by translations in English by other writers. ${ }^{41}$ One such translation appeared in October of the same year, and read as follows.
Of LAN EBOR. should common fame
Again belie the sacred name;
Should your good grace give up the ghost,
Some ages hence in th' Evening Post,
May you yourself, the news before ye,
Laugh in your sleeve, and read the story. ${ }^{42}$

Incidents of this nature left readers like George Legh, vicar of Halifax, wary of taking such news stories about his diocesan at face value. In response to fresh reports of Blackburne's ill-health in October 1737, Legh wrote to Thomas Hayter, the archbishop's chaplain, that "I hope there is as little ground as formerly for [what] occurs in [the] News-papers concerning my Lord [Archbishop's] state of Health". ${ }^{43}$ In this case, it can be observed that the speed at which the

39 The author's forthcoming doctoral thesis at Oxford Brookes University reassesses the functioning of administration and patronage during Lancelot Blackburne's archiepiscopacy.

40 Grub Street Journal, issue 392 (London: Thursday, 30 June 1734); London Evening Post, issue 1032 (London: 29 June - 2 July 1734); Derby Mercury, Vol III, No. 15 (Derby: Thursday 4July 1734); Daily Courant, issue 5694 (London: Thursday 4 July 1734).

41 Gentleman's Magazine (August 1734), p. 445. The epigram also appeared in other periodicals such as the Bee or, Universal Weekly Pamphlet (The Bee Reviv'd), Volume 7, Issue 83 (London: 1733-1734), p. 206.

42 Gentleman's Magazine (October 1734), p. 566. Three years earlier, William Wake, Archbishop of Canterbury, had also been subjected to similar, unfounded rumours. A satirical treatment of this appeared in The Mitre. A Tale In Hudibrastick Verse. Describing three B-sh-ps in Lawn-Sleeves Rowing to Lambeth for a See (London: 1731), p. 3.

43 Borthwick Institute for Archives, Bp C \& P III/7/23, Dr George Legh to Thomas Hayter, 12 October 1737. See also Newcastle Courant, no. 649 (Newcastle: Saturday 1 October 1737). 
news was collated and published led to confusion and the dispersal of misinformation, and false reports became events in themselves, worthy of comment and ridicule. This treatment was extended beyond the clergy to all public figures, as demonstrated by the Caledonian Mercury for 1 July 1734, which noted that "the Dutchess of Northumberland is not dead, tho' some News-mongers have not only killed Her Grace, but buried her at Windsor". ${ }^{44}$ This may call into question the reliability of news during this period, but it is evident that these reports were taken seriously by some until proven to be untrue. In October 1737, the clergyman Thomas Wilson took what he saw in the newspapers sufficiently seriously to call upon Edward Chandler, bishop of Durham, after reading about the death of the prelate's son in the London Gazette. ${ }^{45}$ Wilson was relieved to discover that on that occasion the bishop's son was quite alive, and the Gazette hastily revised their notice in the next day's issue. ${ }^{46} \mathrm{~A}$ swift correction could prevent the impact of an incorrect report, but some newspaper proprietors were particularly assiduous in ensuring that mistakes made by a rival print did not pass by unnoticed. On 18 February $175^{2}$ the Protestant York Courant reported that Henry Goodricke had been installed into the Prebend of Grindal at York Minster, "and not Givendale, as was mentioned in another Courant". ${ }^{47}$ This declaration is a strong reflection of the highly partisan local print market that existed in York in the mid-eighteenth century, but it is also indicative of the continued importance of perceived reliability in reporting the news. By calling into question the veracity of a relatively minor report of ecclesiastical intelligence, the printers of the Protestant York Courant aimed to gain a commercial advantage over their competitor by undermining the reliability of their product.

\section{Clergymen and the Dispersal of News}

Whilst the depiction of the clergy in news reports can be detected through analysis of the contents of eighteenth-century newspapers, to discover ways in

44 Caledonian Mercury, Issue 15993 (Edinburgh: Monday, 1 July 1734).

45 C.L.S. Linnell, The Diaries Of Thomas Wilson, D.D., 1731-37 and 1750, Son of Bishop Wilson of Sodor and Man (London: S.P.C.K., 1964), p. 214; London Gazette, Issue 7645 (London: 15 October $1737-18$ October). Richard Chandler (c. 1703-1769). The London Gazette's mistake came when reporting on James Gambier's appointment as Solicitor of the Excise, initially stating that the position had been vacated due to Chandler's death. This was corrected to state that Chandler had in fact been made a Commissioner of the Customs.

46 London Gazette, issue 7646 (London: 18 October 1737 - 22 October).

47 Protestant York Courant, issue 326 (York: Tuesday 18 February 1752). 
which churchmen consumed news, it is necessary to turn to surviving personal papers, such as financial accounts, commonplace books, correspondence and diaries. Evidence from these sources reveals that at the turn of the eighteenth century, news concerning matters of Church and State was perceived to originate in London and then radiated outwards to the regions, augmenting existing lines of communication. In January 1703, within a year of the appearance of the first daily newspaper in Britain, Thomas Blofield MP wrote from Westminster to Humphrey Prideaux, Dean of Norwich, that he had little fresh information about the ongoing dispute in Convocation other than what Prideaux would have already seen in the public prints. ${ }^{48}$ The regular correspondence between Edmund Gibson, rector of Lambeth, and William Nicolson, Bishop of Carlisle, from the 1700 s to the 1720 , reveals that the two men often reflected on domestic and foreign issues read in the 'public prints', and that they consumed printed news in tandem with information transmitted through correspondence. The delivery of one form of news occasionally outpaced the other, as acknowledged by Gibson in June 1712, who wrote, "I need not tell your Lp what our Generals and Soldiers are doing abroad: because you will see that at large in the publick Papers of [this] day".49

That London was deemed to be the principal stage of the news in matters of Church and State is hardly unexpected, but there was an acknowledged exception to this model during election years, when the "scene of News" was, as Edmund Gibson described it, "remov'd from London to the Country", and public discourse became dominated by comparing "Intelligences from Counties and Burroughs" ${ }^{50}$ Whilst provincial newspapers of the 1720 and 1730 largely followed this model by emphasising national and foreign news over local occurrences, they did provide a more readily available digest of the news for readers in the country. This is reflected in the notes of Robert Marsden, Archdeacon of Nottingham, who between 1724 and 1735 transcribed excerpts and pasted cuttings from London and Nottingham newspapers in his commonplace book. ${ }^{51}$ Whilst many of these notes are taken from curious reports of thefts and extraordinary feats, it is clear that Marsden did not rely solely on the London

48 Cornwall Record Office, $\mathrm{PB} / 8 / 4$, letter from Thomas Blofield to Humphrey Prideaux, 9 January 1703 .

49 Bodleian Library, Add. MS. A. 269, copy letter from Edmund Gibson to William Nicolson, 24 June 1712.

50 Staffordshire Archives, D1057/M/J/11, letter from Edmund Gibson to John Hough, 17 March 1722 .

$5^{1}$ Nottinghamshire Archives. DD/TS/14/2, commonplace book [of Robert Marsden], 1724-35. 
prints for political news, recording in March 1730 details relating to the Pension Bill taken out of the Nottingham Courant. More significant to our understanding of the consumption of news in this period is a "key to the news-papers" drawn up by Marsden in February 1732. The key gives brief, descriptive notes on the backgrounds of twelve London newspapers; the Craftsman, Fogg's Journal, the Daily Courant, the London Journal, the Free Briton, the Hyp-doctor, the Grub Street Journal, the Universal Spectator, the Auditor, the Weekly Miscellany, the London Crier and Applebee's Journal. Of those opposing the government, Marsden described Mist's Journal as a "Tory-paper", and the Craftsman as "writt" . by" William Pulteney, whereas the Daily Courant is noted as being "on the Side of the Ministry", and the London Journal written by "a client of Sr.R.W's.". In the latter case, Marsden's High Churchmanship can be detected in his speculation that Walpole's client was in fact "a Deist". ${ }^{2}$ The key also comments on the style of the newspapers, remarking that the Auditor is "Ingenious", whereas the Universal Spectator is dismissed as "dull". ${ }^{3}$ Whilst Marsden's key provides an exceptional insight into one man's views on the market for news during this period, Marsden was not unique in his reading habits, nor were newspapers the sole preserve of clergymen of the Church of England. ${ }^{54}$ The Lancashire dissenting minister Peter Walkden transcribed dozens of news items at great length in his diary of the mid-1730s, taking reports from at least ten different London newspapers. Walkden also took in some of the earliest issues of a local title, Adam's Chester Courant, but suspected the newspaper of Jacobite sympathies. ${ }^{55}$ These private records demonstrate the degree to which individuals who were permanently resident in the North could be highly engaged with, and knowledgeable of the political inclinations of a wide variety of London newspapers, and also acted as some of the earliest consumers of the first provincial news titles.

These examples are drawn from sources identifiable within the archival record as created by clergymen and ministers, but it is apparent that the personal records of the laity can be equally instructive, particularly in the case of early provincial newspapers. A surviving account book of Hugh Bethell of Rise in the

\section{$5^{2} \quad$ Ibid.}

53 Ibid.

54 In the South of England, Benjamin Rogers, rector of Carlton in Bedfordshire, was a reader of the Northampton Mercury from the late 1720s, and made notes in his diary of reports that interested him. See C.D. Linnell (ed.), The Diary of Benjamin Rogers, 1720-1721 (Streatley: Bedfordshire Historical Record Society, 1950), pp. 17, 22, 38-39.

55 Chipping Local History Society (eds.), The Diary of the Reverend Peter Walkden for 1733-1734 (Otley: Smith Settle, 2000). 
East Riding of Yorkshire gives details of expenditure relating to newspapers, and is highly illuminating of the relationship between a parson and landowner in a rural parish. ${ }^{56}$ Jaques Sterne, mentioned above in relation to his involvement with the York Gazetteer, was rector of Rise for the entire period covered by Bethell's account book, and his influence can be detected in attracting political allies as subscribers and financial supporters to the newspaper enterprises of York during a period of sharp political and religious division. The accounts reveal that Bethell made subscription payments for the York Gazetteer from 1743 until 1746, and from 1746 until his death in 1752, he subscribed to the York Journal; or, Weekly Advertiser. ${ }^{57}$ This staunchly Whig, and anti-Catholic newspaper was printed by John Gilfillan from November 1745, in direct response to the Jacobite Rebellion. By March 1746, the newspaper changed its title to the more confrontational Protestant York Courant, in a direct slur against the supposed political and religious inclinations of the rival York Courant. ${ }^{58}$ The accounts reveal that on at least two occasions Bethell provided Jaques Sterne with additional funds to 'encourage' the publication of Gilfillan's newspaper, firstly within a month of its initial publication, and then again a year later. ${ }^{59}$

Surviving evidence also demonstrates that beyond providing financial backing for the York Journal; or, Weekly Advertiser, Jaques Sterne was also closely involved in the collation of information to be printed in the newspaper. Sterne utilised his patronage network to assist in the business of tracing the most upto-date accounts of the opposing armies during the course of the Rebellion, which included individuals such as the ecclesiastical lawyer Francis Topham, and his nephew, George Fairfax, who was also a clergyman. ${ }^{60}$ Once intelligence had been gathered, it was jealously guarded to ensure that it could be printed in the YorkJournal; or, Weekly Advertiser before it appeared in the pages of its rival. A letter from the York lawyer, Jerom Dring, describes the way in which

$5^{6}$ East Riding of Yorkshire Archives \& Local Studies Service, DDRI/acc. 2980, Hugh Bethell of Rise Hall account book, 1725-1752. For more background, see Daniel Reed, 'A New Historical Perspective on Jaques Sterne in the East Riding: The Account Book of Hugh Bethell of Rise, 1725-1752', The Shandean, 23 (2012), pp. 98-105. See also East Riding of Yorkshire Archives \& Local Studies Service, DL/1/12, Marmaduke Constable's memoranda book, 1738-1749.

57 Ibid.

58 All but six known copies of the York Journal; or, Weekly Advertiser (later, Protestant York Courant) survive in three volumes held by the Laurence Sterne Trust, and York Explore Library, respectively.

59 East Riding of Yorkshire Archives \& Local Studies Service, DDRI/acc. 2980, Hugh Bethell's account book, $1725^{-175^{2} \text {. }}$

60 John Wright, 'Out in the Forty Five', The Antiquary, 23 (Feb. 1891), pp. 74-75. 
an account of an address from Sir Everard Fawkener, secretary to the Duke of Cumberland, to the Magistracy of Liverpool, was prepared for publication in the York Journal; or the Weekly Advertiser of 10 December $1745^{61}$

This I had from Dr. Sterne, under a promise not to give a copy to any Body, from $\mathrm{w}^{\mathrm{ch}}$ I can only understand that he chooses to have the intire propogation of it; for it seems to be worth making public. I fancy the Reason has only been to prevent Ward from having it in his paper [York Courant], for I hear Gilfillan is to have it in his. ${ }^{62}$

The numerous official orders, proclamations, speeches, and accounts of military manoeuvres that were published during the Rebellion were forms of information which newspapers were particularly suited to disseminate. In a letter of 9 August 1746, Thomas Cheyney, Dean of Lincoln, wrote to Archbishop Thomas Herring to thank him for a cutting from the York Journal; or, Weekly Advertiser which gave a report of the Duke of Cumberland's arrival in York following his victory at the Battle of Culloden. ${ }^{63}$ The report appeared in the issue of 29 July 1746, and included a full transcript of Herring's speech on that occasion, with the Duke's reply. ${ }^{64}$ Dean Cheyney explained his particular pleasure in receiving the cutting from the newspaper, as it, "gave me [the] pleasure of reading [what your] Grace spoke to [the] Duke [with] So much Propriety sooner [than] otherwise I [could] have done". 65 These instances demonstrate that during a time of national crisis, clergyman utilised newspapers as a key tool in the direction of the clerical and civil response to the Rebellion.

\section{Religion for Sale}

Having outlined that provincial printers maintained distinct commercial relationships with the Church as an institution, and with individual clergymen as consumers, it is also apparent that they harnessed the general popularity of religion through the advertisement, and dispersal of religious texts. Within

\footnotetext{
61 YorkJournal; or the Weekly Advertiser (York: 10 December 1745).

62 John Wright, 'Out in the Forty Five', The Antiquary (Jan. 1891), pp. 30-37.

63 Borthwick Institute for Archives. Bp. C \& P IV/18, letter from Thomas Cheyney to Thomas Herring, 9 August 1746.

64 York Journal: or, The Protestant Courant (York: 29 July 1746).

65 Borthwick Institute for Archives. Bp. C \& P IV/18, letter from Thomas Cheyney to Thomas Herring, 9 August 1746.
} 
the broader landscape of the eighteenth-century print market, the emergence of provincial newspapers coincided with the 'golden age' of sermon culture in Britain, in which sermons constituted "a major part of the output of the print industry and a significant element in the cultural fabric of the country". 66 These texts were at the forefront of popular, mainstream literature, with an estimated eight times as many pages of sermons printed as fiction during the eighteenth century. ${ }^{67}$ The development of provincial newspapers in the North of England provided an opportunity for printers to advertise the multitude of religious texts produced from their own presses, and to gain revenue by promoting other booksellers and traders. This can be observed in the earliest Northern newspapers, such as the New-Castle Gazette for 23-25 December 1710, which promoted religious texts in three of the four advertisements carried in that issue. ${ }^{68}$ The Church was not passive to these developments, and exhibited sensitivity to the manner in which religious texts were advertised in provincial titles. In February 1727, Edward Wells wrote to William Wake, Archbishop of Canterbury, enclosing a cutting from the Stamford Mercury, in order to alert the primate that his name, alongside that of Robert Marsden, Archdeacon of Nottingham, had been associated with a religious work he viewed as "an Illdigested Confused Heap of Materials taken out of Bp Andrews" ${ }^{69}$ Evidently, it was not improper for the potential misuse of the names of the higher clergy in advertisements to be addressed to the head of the Church of England directly.

As the provincial print marketplace became more competitive, printers experimented with the inclusion of supplementary publications to promote circulation and increase subscriptions to their newspaper titles, offering maps, song-sheets and religious texts either at discounted prices, or given away freely. ${ }^{70}$ This device was used extensively by the London newspaper printer Robert Walker, who serialised works such as the Exposition of the Common Prayer and the History of the Holy Bible in his newspapers directed to markets outside of the capital, such as the Derbyshire Journal and the Lancashire Journal. ${ }^{71}$ The two religious works were purported to be written by one Laurence Clarke, a clergyman of the Church of England, although it is likely that Clarke was

66 William Gibson, 'The British Sermon 1689-19o1: Quantities, Performance, And Culture', in Keith A. Francis and William Gibson (eds.), The Oxford Handbook of the British Sermon 1689-1901 (Oxford: Oxford University Press, 2012), pp. 3-30, (p. 6).

67 Ibid.

68 The New-Castle Gazette; or, the Northern Courant, no. 65 (Newcastle: 23 December 1710).

69 Cornwall Record Office, $\mathrm{PB} / 8 / 5$, letter from Edward Wells to William Wake, 21 February 1727 .

70 Wiles, Freshest Advices, pp. 109-110.

71 Ibid., pp. 437-443. 
fictitious and that the name was employed as a commercial technique to add legitimacy to the publications. The two works were produced concurrently in the summer of 1737 , and were subsequently offered as detachable supplements with continuous pagination to be collected by readers and bound into a volume. Initially, Walker attempted to issue the Exposition of the Common Prayer as a discreet, serialised publication in wrappers containing news content in an attempt to avoid newspaper taxes, and an advertisement of August 1737 demonstrates that he intended to follow the same course with the History of the Holy Bible, which was designed to make up two volumes in around one hundred numbers.

One Sheet in Quarto, neatly stitched up in large Covers, on which Covers will be printed the freshest News Foreign and Domestick, as in the Daily Papers, will be published every Wednesday. ${ }^{72}$

To further lure potential customers, these sheets were to be embellished with occasional cuts, and a new serialisation of Hudibras, accompanied by its own engravings by Hogarth. ${ }^{73}$ The works were recommended "to the Perusal of all Families, being very proper for instructing Children in the Rudiments of the Christian Religion", and the price of two pence each, that the "poorer sort" may have access to the works. ${ }^{74}$ Walker managed to avoid the tax for ten months before it was insisted that he used stamped paper for his half-sheet news wrappers. ${ }^{75}$ Thwarted in his attempts to avoid the duty, Walker proceeded to attach the serialised texts to his newspaper ventures in an attempt to secure a dedicated readership for his provincial titles. Surviving copies of Walker's publications from 1738 and 1739, such as the Lancashire Journal: with the History of the Holy Bible, gave equal prominence to both the imprint of the newspaper and the supplementary religious work..$^{76}$ Other titles, such as the Hull Courant, were also accompanied by serialised sheets of the History of the Bible, although the precise nature of Walker's involvement with this newspaper is unknown. ${ }^{77}$

72 Laurence Clarke, Exposition of the Common Prayer, no. III (London, Wednesday 3 August 1737).

73 Ibid.

74 Ibid.

75 Wiles, Freshest Advices, p. 112.

76 Ibid., p. 448. See also titles such as The Warwickshire and Staffordshire Journal: with the History of the Holy Bible, no. LXXXII (London: 8 March 1739).

77 W.G.B. Page, 'Notes on Hull Authors, Booksellers, Printers, and Stationers, etc.', in Frank Karslake (ed.), Book Auction Records, vol. 6, Part 1, Oct. 1 to Dec. 311908 (London: Karslake \& Co., 1909), pp. i-vii. No issue of this date survives, but it is likely that Page had access to 
It is possible that by 1739 , the London printer wished to downplay his association with titles issued into the North, as his commercial techniques came under criticism. In response to the appearance of Walker's Derbyshire Journal, the rival Derby Mercury published an advertisement for Laurence Howell's history of the Bible, describing the work as being of "establish'd Reputation", as opposed to the works attributed to Clarke, which were blasted as being "pirated". ${ }^{78}$ The Derby Mercury added that Walker's claims that his Derbyshire Journal produced in London could provide more up-to-date news than a country journal were "ridiculous". ${ }^{79}$ In this instance, it can be observed that the aggressive marketing techniques adopted by Walker prompted provincial printers to defend both their own products, and the veracity of the religious texts advertised in the pages of their newspapers.

\section{Conclusion}

When investigating the place of religion in relation to newspaper development in the eighteenth century, digital databases have made many news titles of that period more accessible than ever before, opening up untold avenues for new research. In the case of early provincial newspapers, however, many titles are unlikely to become available in the scope of current digitisation projects, and future accessibility would be reliant on initiatives taken at the few individual repositories which hold physical copies. Until such time, digital research methods can only reveal part of the picture, and it is one that remains heavily London-centric. Wider research using other archival sources goes some way to make up for the current limitations of these resources, and is crucial when investigating issues of newspaper authorship, financing and readership. These aspects of the printing trade can be detected at regional level for individual newspaper titles, but references in the archival record are extremely scarce. When these secondary references can be discovered, however, they offer rare opportunities to augment information taken solely from the close-reading of

copies of the Hull Courant which were known to exist at the turn of the twentieth century, but are now lost.

78 Laurence Howell was a non-juring clergyman whose popular three-volume history of the Bible was first published posthumously in 1725. See Robert D. Cornwall, 'Howell, Laurence (c.1664-1720)', in The Oxford Dictionary of National Biography (Oxford: Oxford University Press, 2004); online edition: http://www.oxforddnb.com/view/article/13977 (accessed 6 June 2016).

Derby Mercury, vol. viI, no. 15 (Derby: Thursday 29 June 1738). 
newspapers, and hint at pathways for future studies, such as more rigorous analysis of the reading habits of distinct social groups such as the clergy.

In the North of England, the emergence of local newspaper enterprises in the early eighteenth century represented a development in the relationship between printers and the clerical profession which had existed since the early modern period, and was reinforced both commercially and legally by the provisions of the Licensing Act of 1662 . The instrumental roles taken by clergymen in the establishment and financing of two of York's three newspapers by 1746, is indicative of a relationship between the Church and the press that developed rather than diminished into the mid-eighteenth century. The affairs of the clergy, particularly their changing health and preferments, continued to feature among the regular dispatches of many Northern newspaper titles, reflecting a broader interest in the lives of public figures and their relative positions within local structures of governance that were of particular consequence to a provincial readership. This perhaps reached its most succinct form in the $175 \mathrm{os}$, when York newspapers published concise lists of the noblemen who had died in the previous two years. ${ }^{80}$ The influence of churchmen as readers of newspapers can also be observed from the mid-century onwards in advertisements which addressed the clergy directly as consumers. ${ }^{81}$ In the later eighteenth century, the Church also began to utilise newspapers in new ways, and more directly as a tool of ecclesiastical administration. Whereas in the first half of the century, details of diocesan events such as ordinations, and confirmation and visitation tours were reported irregularly as local intelligence, it was not until the 1760 s that formal advertisements were taken out in Yorkshire newspapers to mobilise individuals to attend these occasions. ${ }^{82}$ These developments in the relationship between the Church and the press are highly indicative of the continued centrality of religion to British society, in which the role of the clergy in contributing to, and shaping print culture in this period should not be underestimated. The reintroduction of religion to the forefront of the discussion of newspaper development offers alternative pathways and modifications to narratives of secularisation, and notions of 'the Enlightenment', the parameters of which continue to be interrogated, reassessed, and reinterpreted.

\footnotetext{
$80 \quad$ Protestant York Courant, issue 282 (York: Tuesday 16 April 1751).

81 Charles Pearson addressed an advertisement for his robemakers business to 'the Reverend the Clergy'. See, Protestant York Courant, no. 259 (York: Tuesday 6 November 1750).

82 Borthwick Institute for Archives. Bp C \& P III/29, letter from Sir Hardolph Wasteneys to Lancelot Blackburne, $3_{1}$ October 1726; Newcastle Courant (Newcastle: Saturday 3 September 1737); Judith Jago, Aspects of the Georgian Church (London: Associated University Presses, 1997), pp. 63-64.
} 